\title{
“KA'EN KELUN BA MALU” IN DISTRIBUTION OF CULTURE AND LEVEL OF COMMUNITY PARTICIPATION
}

\author{
Imelda Nahak ${ }^{1}$, Wawan Sobari ${ }^{2}$, Mohamad Anas ${ }^{3}$ \\ Universitas Brawijaya \\ Email : 'nahak.imelda31@gmail.com, ${ }^{2}$ wawansobari@ub.ac.id, ${ }^{3}$ anas_phil@ub.adc.id
}

Keyword :

culture, participation,

planning,

development
DOI :

10.30595/jssh.v3i2.5056

\begin{abstract}
Community participation is very important and contributes to the effectiveness of development planning resulted. However, until now community participation has not been realised ideally. Previous studies have offered various efforts to increase community participation, such us local community initiatives increasing, government and community cooperation increasing, integration of art and planning, role of social capital optimisation, socialisation to the root of community, partisipatory leadership, village funds allocation and young people role optimisation as mobilizers. Unfortunately, there has not been an assessment from cultural side point of view. This qualitative case study examines efforts to increase community participation by considering cultural factors that can contribute to the effectiveness of development planning at village level. Data obtained through in-depth interviews, participant observation and documentation. This study found that culture factor of mamfatin ukunrai could inhibit community participation in Naran Village. The community believes that development planning is the duty of the government so that the community should not participate actively in planning meetings. Therefore, ka'en kelun ba malu model is important because besides its function in reducing the impact of the ukunrai mamfatin culture, this model also confirms that it takes more than just a solution in the structural field and empowerment to increase the low level of community participation caused by cultural factors, whis is through elaboration on the cultural side of the community.
\end{abstract}

\section{INTRODUCTION}

\subsection{Background}

Community participation has been an important topic of study in the world of science since the twentieth century. Many programs and policies fail to achieve their goals due to differences in the characteristics of the region and the population, confirm that the effectiveness and efficiency of development programs will only be achieved when community participates in the planning process. The study conducted by Rostam, et al (2018) proved that community participation has been a trend in scientific research since
2000.

Community participation means carrying out development from the most basic level in society. According to Rostam, community participation is related to 4 things, which are 1) The existence of benefits for people participating, 2) Community participation is a reflection of the basic needs and values of the common goodness, 3) Community participation is a guarantee of the fulfillment of needs, and 4) Community participation aims to produce appropriate decision made in the implementation of development. Thus, realising participatory society is an effort to 
bring development closer to the community.

The Indonesian government began to take an interest in community participation since the implementation of decentralized government system. Through policies related to regional autonomy, each regional government gets the opportunity to adjust the development program that will be implemented with the socio-cultural conditions of the people, hoping that failure in implementing the development program can be reduced. Various studies that have been carried out show that the implementation of the program without involving the community eventually experienced a deadlock. Iswahyudi (2012) conducted a research on the effectiveness of community participation in improving public services in Bantul Regency and found that the accessibility given to the community to participate is still limited so that it has not been able to empower the community optimally.

Other research conducted by Rumensten (2012) found that low public participation in the formation of regional regulations caused the regulations to be revoked because they conflicted with central government regulations. Sagita (2016) then conducted a study by looking more at the failure of the district work performance assessment process due to lack of community participation. This lack of community participation is caused by a lack of socialisation related to work assessment applications so that the community does not understand the assessment mechanism that should be carried out.

Another case with a study conducted by Ompusunggu (2017) which explains the ineffectiveness of development programs carried out in Namo Bintang Village due to the low community participation caused by community apathy and limited accessibility to development planning. Mbeche (2017) then added that in a planning process, the government often uses substantive representation as community representatives so that the results achieved do not really answer the needs of the community because it is based on the interests of certain parties. These conditions indicate that community participation has become a substantial and crucial problem that requires more serious handling.

Community participation has many positive impacts, both for the government and the community as the main beneficiaries. Various other studies that have been carried out have succeeded in identifying opportunities that can be exploited, efforts to increase participation that can be taken as well as the benefits that can be obtained from community participation. Muhlinghaus and Walty (2001) refer to local community initiatives to participate as endogenous personnel who can improve the quality of life of people in the Swiss Mountains. Community participation can increase community awareness to be concerned about the environment in which they live, strengthen social ties and strengthen a sense of belonging to the region. Therefore, the process of making a policy must be able to encourage people to participate.

Community participation is also realised through cooperation between the government and the community. When the government supports the community to participate by opening accessibility to planning, the process of resource mobilization will run smoothly so as to facilitate the process of community empowerment (Pandey \& Miznikov, 2001).

Burford, et al (2012) add that efforts to involve the community can increase the creativity of the government and the community itself. To build community 
participation in Mexico and Tanzania, the government held an art exhibition in order to manage the environment and sustainable development. The public is asked to describe the environmental conditions before and after industrialization and the expected environmental conditions on the canvas. Through this art activity, the government can find out to what extent the community cares about the environment in which they live and live as desired by the community.

Community participation is also closely related to building social capital in the community. Cerar's (2014) study of the complex problems of Tabor's favorite homes and parks in Slovenia shows that when they feel a threat, the initially weak social ties will become even tighter. The community then seeks to build cooperation in order to find solutions to overcome these threats, so that social ties between one another become higher. Studies conducted outside Indonesia generally indicate a high level of community awareness to participate, so that when government accessibility and support is going well, community participation can also be ensured to be good.

It is different to the case of Indonesia which has more diverse conditions of social life. Defina (2012) conducted a study of community participation in community empowerment programs in Klender Village. Defina offers a tiered socialization model to the RT level that makes it easy for the community to understand each program mechanism through the planning system, making it easier for the community to carry out and evaluate the results of development. The model offered by Defina departs from a lack of community understanding of the program being implemented so that it requires further information, especially when planning.

Another study was carried out by
Alyas (2015) in Cabenge Village, Soppeng Regency. Alyas highlighted the leadership side as supporting community participation. He explained that the role of the lurah to persuade the community persuasively, accommodate the community and mobilize the community to maintain the results of development was very effective in increasing community participation. Atmojo, et al (2017) reviewed the effectiveness of the use of village funds in supporting community participation. In addition to village funds, support from the village government is another thing that must be considered. Whereas Fitriani, et al (2017) look more at the role of the young generation as motivators of participation that inspire people to participate independently in North Sumatra.

Comparison between studies conducted in other countries and within Indonesia in general places great emphasis on the socio-cultural living conditions of a society. The very diverse conditions of social and cultural life of the Indonesian people require researchers to be more creative in integrating efforts to increase participation with the socio-cultural life of people in an area. This study discusses the "ka'en kelun ba malu" model as part of efforts to overcome the low level of community participation. The term ka'en kelun ba shame comes from the Tetun language, from the word ka'en which means articulated, kelun which means arm or hand and ba shame which means mutual. Thus, ka'en kelun ba embarrassed means holding hands or doing things together.

In contrast to previous studies that looked more at aspects of social structure and community conditions in terms of the economy, education and village governance, this study took into account cultural factors that exist in society, both as factors that encourage low community 
participation and related efforts that can be taken as a solution. Culture that can have an impact on the low level of community participation is already an academic contribution of this research. Because what causes low community participation comes from cultural factors, the improvement effort needs to look at existing cultural values as a solution to increase community participation.

This research was carried out in the 'Naran' Village of Raimanuk District, Belu Regency, East Nusa Tenggara Province. The researcher found that most people in the village believed that planning for development was part of the duties and responsibilities of the village government so that the community did not need to be involved in the development planning process. People usually refer to this as 'mamfatin ukunrai' which means government affairs. Whereas the community is only the party that carries out the results of government decisions. The community then makes this a selfjustification for their actions not to participate in the village development planning process so that the level of community participation is very low, both in terms of the number of attendances and the number of people who influence the decision making process. This is what underlies researchers to conduct research related to community participation by examining more in terms of culture.

\section{METHOD}

This qualitative case study of village development planning was carried out in Naran Village, Raimanuk District, Belu Regency, NTT Province. Data obtained through in-depth interviews with 12 informants selected by snowball sampling techniques. Informants in this study consisted of former village heads from 2012-2018, village officials, 4 village staff, deputy chairperson of the BPD and TPK chairman, 1 hamlet head, 1 RW and former hamlet head for 49 years, 1 community leader, 1 community member who also serves as head of the posyandu cadre and 1 community member who is rarely involved in village development planning.

Researcher also made direct observations of development planning and studies of planning documents in the form of invitation letters for deliberations, attendance lists, minutes, RPJMDes and RKPDes in Naran Village. Data were analysed using exploratory manufacturing analysis techniques (Yin, 2015). To ensure the validity of the data, the researcher conducted a focus group discussion (FGD) 1 time and confirmed the findings of village government staff.

\section{RESULTS AND DISCUSSION}

\section{"Mamfatin Ukunrai" Culture As A Result Of Community Participation In Development Planning}

The word mamfatin ukunrai comes from Tetum, from the word mamfatin which means business, work, or policy and ukunrai which means leader or government. Thus, mamfatin ukunrai means government affairs, government work or government policy.

The culture of mamfatin ukunrai does not refer to the traditions inherited from generation to generation consciously in order to remain sustainable, but rather to a belief that was born from the habits of the people during the Naran Kingdom, which has influenced the mindset and behavior of the community in such a way, so that community participation in planning development is low.

The culture of mamfatin ukunrai originates from the heritage of people's lives during the royal period. Naran Village is a traditional village that was previously part of the Kingdom of Naran in Raimanuk 
District, Belu Regency, NTT Province. Because it is a former royal territory, the people tend to live by referring to the habits found in society for generations. These habits can be habits that are socialized verbally, non-verbally and both. The culture of mamfatin ukunrai is one of the habits of the community that is socialized through the words and behavior of the people from one generation to the next.

In royal times, native people always taught their children to work hard as farmers or ranchers. Boys are accustomed to working in gardens, fields and tending cattle in the fields. While the daughter helps her mother in the kitchen and weaving at home. Ordinary people believe that only by working hard can they get a decent life. They live by holding on to a very common phrase heard in Naran Village namely serisu hello nu atan ha hello nu nain which means working like a servant, eating like a king.

The aristocracy taught their children how to lead the community. Even noble children have the opportunity to receive formal education. This is because only the nobility who will be given the opportunity to lead the community. The community is not entitled to have a position in the community, even as a guardian of natural products (makleat). In addition to not having the right to hold a position, the community is also not given the authority to engage or intervene in government affairs. The existence of opas as a king's control tool makes the community tends to be the implementing party that is fully compliant with whatever is the government's decision.

The condition in which the government is in charge of running the wheels of government and the community becomes the executor of all forms of government decisions without the authority to intervene then becomes a pattern of life and community holdings from one generation to the next. People usually distance themselves from government affairs and teach their children not to interfere in government affairs. Even the government (king, hamlet head, RW, RT) often reminds the public not to interfere in government affairs.

The people of Naran Village in their daily lives still hold fast to traditional values. People live by adopting habits and values that are seen and instilled by their parents. This is the reason why the culture of mamfatin ukunrai still survives until now.

After the end of the kingdom, the government system was replaced by a centralized system. In a centralized government system, people also still do not have the right to intervene in government decisions because everything related to development policy is determined and controlled by the central government. The public must carry out all forms of decisions made by the government. The habit in which the government organizes the government and the people who carry out whatever is the government's decision ultimately creates community dependence on the government.

This dependency makes the community rely more on the government, especially in development planning. this dependence eventually becomes a habit that forms on its own and puts the government on a different path from the community in the administration of village governance. The community also finally views that their action not to involve themselves in development planning is an appreciation effort for not intervening in the government.

The implementation of democracy since 1999 brought a breath of fresh air to the realm of Indonesian politics. To bring the community closer to the government and service needs, the government 
introduced a system of regional government which became better known as regional autonomy. As explained in chapter I, regional autonomy provides opportunities for local governments to adjust the needs of the community to the conditions of the region, both socially and culturally. Regional autonomy also opens opportunities for the community to elect their village leaders themselves and participate in the work of the village government.

Naran Village began to elect the village head for the first time in 2000 (the results of an interview with Mr. HL on 7 November 2018). Previously, the village head was directly appointed by the regional government (Belu Regent). As the electoral system was implemented directly, stratification in the structure of government began to be more open to the public. People who have the potential and have a high school education or above have begun to be given the opportunity to work as village staff and join village government structures and village-level organizations.

Direct community participation began to be seen since the existence of the PNPMMP program, although it still depends entirely on the program facilitators. In 2015, along with the implementation of the village funding program, an increasing number of people participated in development planning meetings, both at the hamlet and village level. Unfortunately, the level of community attendance in hamlet meetings has not reached $50 \%$ overall. In addition to the low level of community attendance, there are very few people who contribute ideas to influence the decision making process. This is because the parties that mostly submit proposals are the hamlet head, RW, RT and community leaders who are usually active in village office activities.

The mindset of the community greatly determines the attitude of the community in participating. When the community considers that planning for development is not part of their authority, then the hope to foster community initiative to participate will disappear. This study found that the culture of mamfatin ukunrai is a source of a lack of public awareness to participate in the development planning process. The cultural value of mamfatin ukunrai has become a belief and belief that is part of the life of the community, although it is still stated indirectly. In free talks after observing activities, researchers often find mild remarks related to people's choice to participate namely "that the government has a duty, if we carry out what the government says".

Separation of affairs that occurred since the days of the kingdom has become a habit that makes people rely heavily on the government in various government affairs. In other words, people still depend entirely on the government so that very few people take the initiative to participate independently. Whereas the government has given the opportunity to the community to participate, namely by holding meetings at the hamlet level which involves all the people and giving opportunities openly to express their opinions.

This proves that the provision of opportunities by the government to participate does not necessarily guarantee a significant increase in community participation as long as the community still adheres to the culture of mamfatin ukunrai. The community needs to change its mindset slowly, so that it can give birth to initiatives that come from within the community itself to participate in the village development planning process.

Previous explanations show that the culture of mamfatin ukunrai has shifted values with the implementation of the local government system. The government system that was once closed has become 
more flexible. People who were previously not given the right and authority to be involved in government affairs, are now beginning to be given the opportunity by the village government to attend and contribute their opinions in the development planning process. Unfortunately, the culture of mamfatin ukunrai has been internalized and accepted as a belief that justifies community actions not to participate in the development planning process so that it inhibits the community from participating.

Other propositions that arise as a result of the culture of mamfatin ukunrai are as follows: Under certain conditions, culture can encourage community participation to be low even though the village government has opened access to the development planning process. If the attachment of the community to the culture of mamfatin ukunrai is high, then the community will not be able to participate in planning ideally. Vice versa, if the community attachment to the culture of mamfatin ukunrai is low then participation will run more ideally.

Hofstede in (Enserink, Patel, Kranz, \& Maestu, 2007) explained the results of his study of the behavior of IBM employees to find five dimensions of national culture that serve as benchmarks for interaction in society. The five dimensions of national culture are the high or low distance of power, individualism or collectivity, masculinity or feminism, avoidance of uncertainty and long-term orientation or short-term orientation. In this study, researchers tried to reduce these five dimensions in the village development planning system. Researchers found that the five dimensions can be reduced, even in some dimensions it actually produces findings that can add Hofstede's findings.

Regarding power distance, Hofstede explained that power distance had an impact on the process of community interaction. The things that cause the difference in power distance are the level of position and level of education. The higher the level of education and position in society, the distance of power in society will be higher / further. Unfortunately, Hofstede does not take into account social changes that occur in society.

Over time, education and position do not necessarily determine the difference in power distance. Public acceptance of the existence of social stratification in the community itself is more flexible, so that the higher level of education and position is not necessarily followed by a long distance of power. Researchers' findings in the results of this study also add that in the midst of the social changes that have occurred as previously defined, culture can actually make the distance of power far apart, regardless of differences in educational levels and positions in society.

The culture of mamfatin ukunrai is based on the habits of the people who really value their government. Thus, whatever the educational background of the village government concerned, as long as he serves as the village government, the community will respect and respect him. In this case, the culture of mamfatin ukunrai makes the distance of power between the government and the community more distant.

Another dimension is individualism or collectivism. The study produced by Hofstede found that community interaction is based on the interests of individuals or groups. This study adds that the existing social position in the community has an impact on the interests that are the basis of participation.

The results of the study showed that the hamlet head, RW, RT and community leaders who had been trusted by the community would participate on the basis of collectivism interests. This is because 
they have been trusted by the government and the community as the party who knows best what is needed by the community so they must speak on the basis of community interests. While society in general is still based on individual interests. This community's description of the basis of interests shows clearly that the community always views that the matter of taking care of the interests of many people is the task of the village government, while each community is responsible for their personal interests.

Next is the masculine or feminism dimension. According to Hofstede, this dimension is related to the role of women and men in society. In subsequent studies related to Hofstede's research, the roles of men and women were also identified with community attitudes. Masculine society is a society that prioritizes competition while a feminist society is a society that always strives to maintain balance with the aim of maintaining peace. When viewed from the roles of men and women, men still dominate in Naran Village. Both in the village government structure, traditional ceremonies and in the development planning itself. This is because the people of Naran Village are people who live with patriarchal culture so that men still dominate the public sector in society.

Based on community attitudes, people of Naran Village are still classified as feminist. Naran Village Community is a community that still tends to maintain balance so that peace can be created. Competition with each other is not yet seen. The people of Naran Village are traditional people who live according to values and norms that have been in place for a long time. If someone lives outside the values and norms that have been applied then that person will receive social sanctions in the form of gossip and even fines because they are considered to damage the social order in society.
This condition also explains the next dimension of Hofstede namely avoidance of uncertainty. People with a high degree of avoidance of uncertainty will create a set of regulations to anticipate changes that are uncertain in the future. Thus, the level of uncertainty avoidance from the people of Naran Village is very high. It's just that the community does not necessarily create new regulations to anticipate things that are uncertain but still guided by the values and traditions that have been passed down for generations in society.

The final dimension of Hofstede is long-term or short-term orientation. A society with a long-term orientation will adjust to social change so that it will change itself in accordance with the times, while a community with a short-term orientation is a society that is still alive by holding on to traditional values and norms in force. The people of Naran Village are traditional communities, so in their daily lives they naturally hold fast to the values and norms prevailing in society. It is this type of community in Naran Village that has made the mamfatin ukunrai culture persist to this day.

\section{"Ka'en Kelun Ba Malu" As An Effort to Reduce The Impact of Culture to Improve Community Participation in Development Planning.}

Naran Village is a traditional village that has the largest population in Raimanuk District, Belu Regency, NTT Province, which is 2,880 inhabitants. Of this number, the male population is 1,323 people while the female population is 1,557 . When viewed based on livelihoods, $26 \%$ work as farmers, $31 \%$ of the population are not yet employed, $22 \%$ of the population is unemployed, $9 \%$ are housewives, $8 \%$ are laborers, $0.9 \%$ are civil servants, $0.7 \%$ are motorcycle taxis, $0,7 \%$ retired, $0.4 \%$ businessman, $0.2 \%$ mechanic, $0.04 \%$ POLRI and $0.5 \%$ are others. This division of 
population based on livelihoods shows that the number of unemployed residents is quite high, namely $22 \%$. This condition states that community conditions in Naran Village are still underdeveloped.

The level of public education is still classified as very low. $12 \%$ of the population did not attend school because they were under five, $46 \%$ were still in school, $19 \%$ only graduated from elementary school, $4 \%$ only graduated from junior high school, $9 \%$ only graduated from high school, 3\% graduated from graduate school and another $8 \%$ never went to school. The data above shows that the population of Naran Village also has a very low level of education due to the large number of residents who have only graduated from elementary school and never attended school.

The condition of Naran Village residents who are still economically and educationally underdeveloped certainly has an impact on the low level of community participation in Naran Village. Rumensten (2012) explains that the quality of human resources can influence the level of community participation. The level of education of the people of Naran Village is indeed very low, including village government staff.

The results of interviews with 10 of the 12 informants confirmed that although the whole community was invited to attend the planning meeting, the level of community attendance never reached $50 \%$, in fact there were only 5-6 people who shared their opinions when given the opportunity. 5-6 of these people are community leaders or elders who are usually trusted as a conveyor of community aspirations. These people have low levels of education, even some of them have never attended school so when expressing their aspirations, they use more local languages because they cannot speak Indonesian well. However, because they are trusted by the government and the community as people who can influence the decision making process, they are actively involved in planning deliberations.

The government has opened the widest possible accessibility to the community by holding a meeting at the hamlet level that invites all people and provides equal opportunity for all communities to contribute opinions in the discussion session, but of the entire hamlet deliberations held in each hamlet, only hamlet, RW and RT heads who express their opinions (Results of interviews with 4 village staff).

The people of Naran Village also have young people who are relatively well educated, which is $3 \%$ of the total population. However, only 1-2 people participate in development planning. this clearly shows that the culture of mamfatin ukunrai also influences the younger generation, so that although highly educated, they are reluctant to get involved because they feel they have no responsibility to plan development in Naran Village. For this reason, efforts are needed to build public awareness to be more concerned about village development, one of which is to start engaging in the village development planning process. Research Fitriani, et al (2017) strengthen this argument by arguing that optimizing the role of young people can increase community participation.

Conditions described previously show that the low quality of human resources does not have a significant impact on community participation so that improving the quality of human resources is not enough. Even though they have low education, when people get the chance and trust that they are worthy and worthy of fighting for their aspirations, the community will participate. This is 
reinforced by what is said by Munglinghaus and Walty (2001) and Cerar (2014) namely the need for the optimization of the role of social capital in increasing public participation.

Muhlinghaus, Walty and Cerar put more emphasis on local community initiatives as social capital, while this research emphasized trust as social capital to increase participation, both from the government and the community itself. The community needs to be convinced that developing development planning is a shared responsibility between the government and the community.

As stated by Pandey and Miznikov (2001), cooperation between the government and the community needs to be increased to create a participatory society. This cooperation does not mean that the government dominates because of the low education of the people, but the government needs to support, accompany and give trust to the community to participate properly and correctly.

Alyas (2015) in his research explained the importance of leadership factors in increasing public participation. The government can provide opportunities and facilitate the community to create conditions that support the growth of community initiatives to participate. In addition, the government can allocate village funds to facilitate increased community participation. Atmojo, et al (2017) suggested that the allocation of village funds can make community participation increase. Nevertheless, village funds are effective in increasing community participation insofar as the government can adapt them to the sociocultural conditions of the community's life. In the condition of the people of Naran Village who are reluctant to participate, the government can use village funds as an effort to get the community to participate.
Local community initiatives cannot be developed easily in Naran Village because people tend to believe that planning for development is not part of their duties and responsibilities so they are reluctant to participate but that does not mean growing community initiatives is impossible to do.

The initial step that can be taken to increase cooperation between the government and the community is through socialization (Defina, 2012). MM (31 years old), one of the staff of Naran Village, explained that the low level of community participation that occurred in Naran Village was also caused by the lack of socialization related to the development planning mechanism so that both the government and the community did not understand the mechanism related to development planning. this opinion is reinforced by research Sagita (2016).

After 2015, the local government and village assistants often gave outreach but the number of community attendances did not increase, as did the number of people who contributed ideas. The people of Naran Village mostly use the excuse of being busy working to avoid planning deliberations. GJ (34 years) one of the village staff said that when invited, the community tends to reason that they are busy working. Wijaksono (2013) revealed that work patterns can cause low community participation because there is no free time to participate. However, this factor is more a reason for self-justification than an inhibiting factor in the Naran Village community.

Wijaksono's research was conducted in an urban area where the majority of people work in offices so that they are bound by office regulations. Unlike the case with the people of Naran Village, whose majority of residents work as farmers. The community can choose to attend the deliberations because they are not bound by certain rules, especially when the hamlet meetings 
usually do not take up a full day. The researcher considered that the reason for being busy working was an effort to justify the community which originated from the culture of mamfatin ukunrai, in which the community considered that planning for development was the duty of the government so that the community did not need to attend the deliberations.

The culture of mamfatin ukunrai is related to the mindset and mentality of people who are accustomed to surrender all matters related to government to the government. Thus, if the government seeks to increase community participation, the government needs to strive to change the mindset of the people who are still holding on to the culture of mamfatin ukunrai.

The comparisons that the researchers have explained regarding previous studies and the conditions of the Naran Village community indicate that structural and empowerment solutions are apparently not enough to overcome the low level of community participation caused by cultural factors.

Researchers view that to change the mindset of people who have been patterned with the culture of mamfatin ukunrai, the village government needs to change the mechanism of planning deliberations by highlighting the cultural side that can reduce the cultural impact of mamfatin ukunrai. This model is called ka'en kelun ba malu.

The term $k a^{\prime}$ en kelun ba malu is a slogan that has been used by the people of Naran Village, even the people of Raimanuk District in general as an invitation to cooperate. People usually say that " $k a^{\prime} e n$ kelun ba malu, neon ida laran ida, ibun namutuk lian namutuk". This sentence means to join hands, unite in heart and words. When doing things together, the community will be united both in words and deeds in achieving the goal of the existence of ka'en kelun ba malu. Because all members of the community are seen as brothers, so when someone experiences difficulties, other members of the community will unite to lend a helping hand. Thus, ka'en kelun ba malu also symbolizes brotherhood and close unity in society.

The phrase $k a^{\prime}$ en kelun ba malu not only means to work together but also states that in the process of working together, each person has the same rights, authority and responsibilities. In working together, the intentions and goals of the whole community are put together then fought together. Departing from a philosophy where when people join hands, they will move together, both when moving forward or backward. By joining hands too, the bond with each other becomes stronger so that not a single person will fall from being supported by other members.

$K a$ 'en kelun ba malu philosophy has become the motto of community togetherness of the Village of Naran. This movement has even become the main movement in the tebe regional dance, which has been increasingly popular and has been featured in many traditional events, cultural performances and parties held in the community. In the dance, dancers join hands in a circle, then move forward and backward to the rhythm of the music. The movements of the legs are varied and varied, depending on the type of music used, but the hands remain in a holding position, be it in groups of men, women or a combination of men and women.

Ka'en kelun ba malu in traditional ceremonies in Naran Village are usually used when a family will ask for help from fellow members of the tribe or extended family. For example, when the belis of a woman to be married by one of the family members is very expensive, the male family 
will hold a family gathering with the aim of raising money in order to meet the number of belis set by the female family.

One time, when other families need help because of grief or get a burden on the belis too, then families who have received help will return to donate some money. The amount of money given is usually the same or higher than the amount ever received, depending on the economic conditions of each family. This community effort in building cooperation to help one another is what is called $k a^{\prime} e n$ kelun ba malu.

At first, before doing $k a^{\prime} e n$ kelun $b a$ malu, the family will gather together to discuss the amount of dependents of each person based on family relationships. After the amount of the dependents is determined, each family will collect money based on the amount determined. Ka'en kelun ba malu was not only related to raising money, but also related to the division of labor between families. In the event of establishing a new traditional house, the members of the traditional house will do a ka'en kelun ba embarrass by gathering together to discuss the division of labor between the members of the traditional house. Thus, ka'en kelun ba malu is a sign of cooperation that has been used since ancient times until now.

The phrase ka'en kelun ba malu intentionally the researcher chose for this participation model for several reasons, namely this phrase symbolizes the invitation of the village government for the community to establish cooperation with the village government in planning development through deliberations. When using the term $k a^{\prime}$ en kelun ba malu, the community will naturally understand that to plan a village development program, good cooperation is needed between the government and the community. In addition, the use of this term makes it easier for the public to understand the government's intention to carry out planning deliberations, especially for people with low education who cannot speak Indonesian well.

This model can also be integrated with the culture of other Naran Village communities which are currently almost extinct, namely calling the community to gather by blowing trumpets made of buffalo horns (in Tetun called To'is) or hitting gongs. Long before the community knew the invitation letter and the culture of inviting the community verbally, the sound of 'to'is or gong was a sign that the community was asked to gather. When they hear the to'is are being blown or the gong beaten, people will invite each other to gather at the agreed place in advance.

The government can again use to' is or gongs to call on people to gather. By using to'is or gongs, the community will understand that all people are invited to attend the meeting, not only the hamlet head, RW, RT or community leaders who are often relied upon to participate in the development planning process in previous years. In addition, the use of to'is or gongs can also be seen as an effort to preserve and preserve the culture of the community in Naran Village since there are no more people using to'is or gongs, except for one of the kapela (places of worship) in an inland village that is still use to'is to call on people to immediately gather in the chapel because worship will begin soon.

Practical things that can be applied by the village government to realize this kelan ba shame model are as follows:

1) Development planning begins with the implementation of deliberations at the hamlet level.

2) The village government must ensure that all communities are actually invited by the hamlet head to attend the hamlet deliberations which will be carried out by randomly supervising the community in each hamlet. 
3) When the day of deliberations at the hamlet level arrives, the government can invite the community to gather immediately by blowing to'is or hitting the gong.

4) Deliberation activities at the hamlet level are accompanied by several village staff or the planning team as a companion whose task is to guide and direct the community.

5) The village government does not have to always take the place in front when the hamlet, village and village development planning meetings. The village government (village head, village secretary and village staff) can join the participants (especially during the discussion session), conduct a briefing and invite the community to participate in speaking.

6) Change the position of the chairs that have been lined up from front to back into a circle. Then the village head takes a center position and other staff mingle with the participants to direct the participants while the village head or secretary guides the discussion.

7) Delivering at the beginning of the planning meeting that the community can use the local language to express their opinions. In addition, the village head uses regional languages as initial greetings and remarks. In the discussion session, the village head and staff used local languages to ask the community about proposals.

8) The village government must ensure that any socialization involving only representatives is passed on to the community, both through the hamlet head and community leaders by supervising at the hamlet level.

9) To the regional government

a. Creating a more systematic planning reporting system for villages, where each village must report the progress of planning making in order to facilitate supervision, while avoiding hastening planning.

b. Conduct socialization first before a program is implemented to provide an understanding of the community related to the program to be implemented.

c. Supervise when the development planning process to ensure that the planning process is carried out according to established mechanisms.Sinom consists of 29 couplets, Dhandhanggula consist of 31 couplets, Pangkur consists of 43 couplets, and Durma consists of 97 couplets.

\section{CONCLUSION}

The culture of mamfatin ukunrai can inhibit community participation in Naran Village. The community considers that being not participated in the development planning is right thing to do because planning for development is the responsibility of the village government.

The culture of mamfatin ukunrai is related to the mental or mindset of the community so that the culture of mamfatin ukunrai is much more difficult to overcome because it is not easily been seen and expressed clearly by the community. Efforts to change the mindset (mindset) of the community can not be done easily and requires a long process because it is associated with something that is trusted by the community and used as a reference for years.

To reduce the cultural impact of mamfatin ukunrai, researchers consider it necessary to create a participation model that is based on the culture of the people of Naran Village as well. Then the right model is the Ka'en Kelun Ba shame participation model. This model illustrates the culture of community of Naran Village. This model also emphasizes to the community that 
village development will succeed better when the government and the community establish good cooperation in planning, implementing and evaluating each program and policy produced.

\section{REFERENCES}

Alyas. (2015). Lurah dan Partisipasi Masyarakat dalam Pembangunan di Kelurahan Cabenge Kecamatan Lilirilau Kabupaten Soppeng. Sosiohumaniora, 17(1), 84-96.

Atmojo, Eko, M., Fridayani, H. D., Kasiwi, A. N., \& Pratama, M. A. (2017). Efektivitas dana desa untuk pengembangan potensi ekonomi berbasis partisipasi masyarakat di Desa Bangunjiwo Muhammad Eko Atmojo, Helen Dian Fridayani, Aulia Nur Kasiwi, Mardha Adhi Pratama Program Studi Ilmu Pemerintahan, FISIP Univeristas Muhammadiya. ARIST Sosial Politik Humaniora, 5(1), 126-140.

Burford, G., Kissmann, S., Rosado-May, F. J., Dzul, S. H. A., \& Harder, M. K. (2012). Indigenous Participation in Intercultural Education. Ecology and Society, 17(4). Retrieved from http://www.jstor.org/stable/262692 42

Cerar, A. (2014). From reaction to initiative: Potentials of contributive participation. Urbani Izziv, 25(1), 93-106.

https://doi.org/10.5379/urbaniizziv-en-2014-25-01-002

Defina. (2012). The Community Participation and Socialization in Empowering Program ( PPMK) at Klender Village. Penyuluhan, 9(2).

Enserink, B., Patel, M., Kranz, N., \& Maestu, J. (2007). Cultural factors as codeterminants of participation in river basin management. Ecology and Society, 12(2).
https://doi.org/10.5751/ES-02096120224

Fitriani, E., Selinaswati, \& Mardiah, D. (2017). Partisipasi Asyarakat Dalam Pembangunan Ekowisata Sungai Pinang. Socius, 4(1), 83-96.

Iswahyudi, F. (2012). EFEKTIFITAS PARTISIPASI MASYARAKAT DALAM PERBAIKAN PELAYANAN PUBLIK (Studi Kasus Pelaksanaan Peraturan Menteri Pendayagunaan Aparatur Negara Nomor 13 Tahun 2009 tentang Pedoman Peningkatan Kualitas Pelayanan Publik dengan Partisipasi Masyarakat pada Dinas. Jurnal Borneo Administrator, 8(3), 310-340.

Mbeche, R. (2017). Climbing The Ladder of

Participation Symbolic or Subtantive Representation in Preparing Uganda for REDD+. Conservation and Society, 15(4), 426-438.

https://doi.org/10.4103/cs.cs

Muhlinghaus, S., \& Walty, S. (2001). Endogenous development in Swiss mountain communities: Local initiatives in Urnasch and Schamserberg. Mountain Research and Development, 21(3), 236-242. https://doi.org/10.1659/02764741(2001)021\{[\}0236:EDISMC]2.0. $\mathrm{CO} ; 2$

Ompusunggu, V. (2017). Peranan Partisipasi Masyarakat Dalam Perencanaan Pembangunan Desa. Jurnal Sektor Publik, 10(1), 95-102. Retrieved from http://pep3d.jabarprov.go.id/index. php/berita/artikel/77-perananpartisipasi-masyarakat-dalamperencanaan-pembangunan-desa

Pandey, K., \& Miznikov, Y. (2001). Decentralization and Corruption. Mountain Research and Development, 21(October), 226- 


\section{Jurnal \\ JISSH SAINS SOSIAL dan HUMANIORA}

230.

https://doi.org/10.1080/10999922.20 04.11051256

Rostam, N. G., Ansari, M., \& Vinejad, M. M. (2018). A Scientometric Review of Citizen Participation Research World Trend. Theoretical and Empirical Research in Urban Management, 13(3), 97-114. https://doi.org/10.5379/urbaniizziv-en-2010-21-02-006

Rumensten, I. (2012). Model Ideal Partisipasi Masyarakat Dalam Pembentukan Peraturan Daerah. Jurnal Dinamika Hukum, 12(1), 135-148.
https://doi.org/10.1017/CBO978110 7415324.004

Sagita, N. I. (2016). Partisipasi Warga Masyarakat Dalam Penilaian Kinerja Kecamatan Di Kota Bandung. CosmoGov, 2(2), 308-329. https://doi.org/10.24198/cosmogov. v2i2.10009

Wijaksono, S. (2013). Pengaruh Lama Tinggal Terhadap Tingkat Partisipasi Masyaraka Dalam Pengelolaan Lingkungan Permukiman. Journal ComTech BINUS, 4(1), 24-32. 